\title{
Inhibition of Heme Oxygenase Antioxidant Activity Exacerbates Hepatic Steatosis and Fibrosis In Vitro
}

\author{
Marco Raffaele ${ }^{1}$, Giuseppe Carota ${ }^{1}$, Giuseppe Sferrazzo ${ }^{1}$, Maria Licari ${ }^{1}$, Ignazio Barbagallo ${ }^{1}(\mathbb{D}$, \\ Valeria Sorrenti ${ }^{1}$, Salvatore S. Signorelli ${ }^{2}$ and Luca Vanella ${ }^{1, *(1)}$ \\ 1 Department of Drug Science, Biochemistry Section, University of Catania, 95125 Catania, Italy \\ 2 Department of Clinical and Experimental Medicine, University of Catania, 95125 Catania, Italy \\ * Correspondence: lvanella@unict.it; Tel.: +39-095-7384077
}

Received: 10 June 2019; Accepted: 1 August 2019; Published: 5 August 2019

\begin{abstract}
The progression of non-alcoholic fatty liver disease (NAFLD) and the development of hepatic fibrosis is caused by changes in redox balance, leading to an increase of reactive oxygen species (ROS) levels. NAFLD patients are at risk of progressing to non-alcoholic steatohepatitis (NASH), associated to cardiovascular diseases (CVD), coronary heart disease and stroke. Heme Oxygenase- 1 (HO-1) is a potent endogenous antioxidant gene that plays a key role in decreasing oxidative stress. The present work was directed to determine whether use of an inhibitor of HO-1 activity affects lipid metabolism and fibrosis process in hepatic cells. Oil Red assay and mRNA analysis were used to evaluate the triglycerides content and the lipid metabolism pathway in HepG2 cells. ROS measurement, RT-PCR and Soluble collagen assay were used to assess the intracellular oxidant, the fibrosis pathway and the soluble collagen in LX2 cells. The activity of HO-1 was inhibited using Tin Mesoporphyrin IX (SnMP). Our study demonstrates that a non-functional HO system results in an increased lipid storage and collagen release in hepatocytes. Consequently, an increase of HO-1 levels may provide a therapeutic approach to address the metabolic alterations associated with NAFLD and its progression to NASH.
\end{abstract}

Keywords: heme oxygenase; HO-1 inhibitor; NAFLD; hepatocytes; collagen; oxidative stress

\section{Introduction}

Hepatic steatosis is a common liver disease characterized by the presence of triglycerides vesicles, accumulating within hepatocytes [1]. It is associated with dyslipidaemia, obesity and insulin resistance, despite a diet with low alcoholic drink consumption: this condition is known as non-alcoholic fatty liver disease, or NAFLD [2-7]. NAFLD has become a critical problem for public health, because of the involvement of other collateral cardiometabolic diseases, including diabetes and hypertension [8-12]. NAFLD patients are at a risk of progressing to non-alcoholic steatohepatitis (NASH) and ultimately cirrhosis; they are also at a higher risk of cardiovascular diseases (CVD), including coronary heart disease and stroke [13]. NAFLD confers increased cardiovascular disease risk independent of traditional cardiovascular risk factors and metabolic syndrome [14]. The abnormal accumulation of lipids in the liver causes non-alcoholic steatohepatitis (NASH) with progressive liver damage characterized by inflammation and oxidative stress, that could lead to advanced fibrosis or cirrhosis [15-17]. In the case of repeated damage, liver parenchyma could respond with an excessive extracellular matrix (ECM) accumulation, due to activation of hepatic stellate cells (HSCs) in perisinusoidal space [18,19]. After differentiation in myofibroblast-like cells, HSCs play a key role in ECM remodeling through the overexpression of $\alpha$-smooth muscle actin ( $\alpha$-SMA), that leads to hepatic fibrosis [20-23]. An imbalance of ECM synthesis and degradation is caused by the activity of many mediators, such as mitogen-activated protein kinase (MAPK), integrins and various growth factors [24,25]. Transforming growth factor $\beta$ 
(TGF- $\beta$ ) is a key mediator in fibrotic matrix increase [26] as the main pro-fibrogenic cytokine, promotes the accumulation of ECM through both activation of SMAD-dependent and independent pathways, and regulation of enzymes like metalloproteinases [27-30]. The progression of NAFLD and the development of hepatic fibrosis is caused by changes in redox balance, leading to an increase of reactive oxygen species (ROS) levels [31-33]. Heme oxygenase (HO) is a microsomal enzyme involved in oxidative stress control, that catabolizes heme into biliverdin, ferrous iron $\left(\mathrm{Fe}^{2+}\right)$ and carbon monoxide (CO) [34-36]. HO exerts an antioxidant effect through its products, which possess many biological protective properties involved in the regulation of inflammation and apoptosis [37]. Cytoprotective actions of $\mathrm{HO}$ and its by-products can be harmful, especially when translated into pathophysiological processes like tumorigenesis [38-42].

Humans own two isoenzymes of HO, namely HO-1 and HO-2, encoded by the HMOX1 and HMOX2 genes, respectively. Also known as heat shock protein $32, \mathrm{HO}-1$ is induced in a range of cells and in several organs, in response to inflammation and oxidative stress, while HO-2 is constitutively expressed [43-47]. It has been shown that HO-1 ensures a protective effect on liver cells under injury conditions, and an induction of HO- 1 is even involved in the prevention of liver fibrosis development $[48,49]$. Conversely, low levels of HO-1 are related to severe oxidative stress and organ failure, showed by iron deposits in the damaged liver [50]. The aim of this study is to investigate the role of $\mathrm{HO}$ in two of the main processes involved in the NASH pathology, using the human hepatocellular carcinoma cell line (HepG2) treated with free fatty acids (FFA), and the human hepatic stellate cells (LX2) treated with TGF- $\beta$, as steatosis and fibrosis models, respectively.

\section{Materials and Methods}

\subsection{Cell Culture}

HepG2 cells retain many characteristics of normal differentiated quiescent hepatocytes. They were widely used in several studies as NAFLD in vitro model, administrating fatty acids [51-53]. HepG2 cells were maintained in DMEM supplement with $10 \%$ FBS, $1 \%$ Penicillin and Streptomycin solution and incubated at $37{ }^{\circ} \mathrm{C}$ in a $5 \% \mathrm{CO}_{2}$ humidified atmosphere. For the experiments, the cells were seeded in 24-well plates at a density of $5 \times 10^{5}$ cells per well. Then the cells were treated for $24 \mathrm{~h}$ with DMEM containing FFA $2 \mathrm{mM}$ (palmitic acid and oleic acid 2:1) in the presence or absence of TinMesoporphyrin IX (SnMP) $5 \mu \mathrm{M}$, alone or in combination with Cobalt Protoporphyrin (CoPP) $5 \mu \mathrm{M}$, for $2 \mathrm{~h}$ as pre-treatment.

The LX2 cells were maintained in medium DMEM low glucose supplemented with $10 \%$ FBS and $1 \%$ Penicillin and Streptomycin solution. For this study, the cells were seeded in 6-well plates and then treated with $5 \mathrm{ng} / \mathrm{mL}$ TGF- $\beta$ to induce their activation and the collagen release, in the presence or absence of SnMP $5 \mu \mathrm{M}$ and CoPP $5 \mu \mathrm{M}$.

\subsection{Oil Red O Staining}

Staining was performed using $0.21 \%$ Oil Red O in 100\% isopropanol (Sigma-Aldrich, St. Louis, MO, USA). Briefly, hepatocytes were fixed in 10\% formaldehyde, stained with Oil Red O for 10 minutes, rinsed with $60 \%$ isopropanol (Sigma-Aldrich), and the Oil Red O eluted by adding 100\% isopropanol for 10 mins and the optical density (OD) measured at $490 \mathrm{~nm}$, for $0.5 \mathrm{sec}$ reading. Lipid droplets accumulation was examined by using an inverted multichannel LED fluorescence microscope (Evos, Life Technologies, Grand Island, NY, USA).

\subsection{ROS Measurement}

Determination of ROS was performed by using a fluorescent probe $2^{\prime}, 7^{\prime}$-dichlorofluorescein diacetate (DCFH-DA); $100 \mu \mathrm{M}$ DCFH-DA, dissolved in 100\% methanol which was added to the cellular medium and the cells were incubated at $37^{\circ} \mathrm{C}$ for $30 \mathrm{~min}$. Under these conditions, the acetate group is not hydrolyzed [54]. The fluorescence [corresponding to the oxidized radical species 
$2^{\prime}, 7^{\prime}$-dichlorofluorescein (DCF)] was monitored spectrofluorometrically (excitation, $\lambda=488 \mathrm{~nm}$; emission, $\lambda=525 \mathrm{~nm}$ ). The total protein content was evaluated for each sample, and the results were reported as percentage increase in fluorescence intensity (FI)/mg protein with respect to control untreated cells.

The quantitative measurement of cellular populations undergoing oxidative stress was performed using the Muse Oxidative Stress Kit (Merck Millipore, Billerica, MA, USA), according to the manufacturer's instructions. This assay utilizes dihydroethidium (DHE), which is cell membrane-permeable and, upon reaction with superoxide anions, undergoes oxidation to form DNA-binding fluorophore. The kit determines the percentage of cells that are negative [ROS(-)] and positive $[R O S(+)]$ for reactive oxygen species. The count and percentage of cells undergoing oxidative stress were quantified using the Muse Cell Analyzer and Muse analysis software (Merck Millipore, Milano, Italy).

\subsection{Sircol Collagen Assay}

Total soluble collagen in cell culture supernatants was quantified using the Sircol collagen assay (Biocolor, Belfast, UK). For these experiments, confluent cells in 6-plate wells were incubated for $24 \mathrm{~h}$ with $5 \mathrm{ng} / \mathrm{mL}$ of TGF- $\beta$ (Sigma). One $\mathrm{mL}$ of Sirius red stain, an anionic dye that reacts specifically with basic collagen side chain groups, was added to $400 \mu \mathrm{L}$ of supernatant and incubated with gentle rotation for $30 \mathrm{~min}$ at room temperature. After centrifugation at $12,000 \mathrm{~g}$ for $10 \mathrm{~min}$, the collagen-bound dye was dissolved again after the addition of $1 \mathrm{~mL}$ of $0.5 \mathrm{M} \mathrm{NaOH}$ and absorbance at $540 \mathrm{~nm}$ was measured using a microplate spectrophotometer reader (Synergy HT, BioTek). The absorbance was directly proportional to the amount of newly formed collagen in the cell culture supernatant.

\subsection{RNA Extraction and $q R T-P C R$}

RNA was extracted by Trizol reagent (Invitrogen, Carlsbad, CA, USA) [4]. First strand cDNA was then synthesized with Applied Biosystem (Foster City, CA, USA) reverse transcription reagent. Quantitative real-time PCR was performed in Step One Fast Real-Time PCR System Applied Biosystems using the SYBR Green PCR MasterMix (Life Technologies) [5]. The specific PCR products were detected by the fluorescence of SYBR Green, the double stranded DNA binding dye. The relative mRNA expression level was calculated by the threshold cycle $(\mathrm{Ct})$ value of each PCR product and normalized with that of GAPDH by using comparative $2^{-\Delta \Delta C t}$ method.

\subsection{Statistical Analyses}

Statistical significance $(P<0.05)$ of differences between experimental groups was determined by the Fisher method for analysis of multiple comparisons. For comparison between treatment groups, the null hypothesis was tested by either the single-factor analysis of variance (ANOVA) for multiple groups, or the unpaired t-test for two groups, and the data are presented as mean $\pm \mathrm{SD}$.

\section{Results}

\subsection{Effect of HO Inhibition on Hepatic Fatty Storage}

HepG2 cells were treated with FFA $2 \mathrm{mM}$ in order to create an in vitro model of hepatic steatosis. After $24 \mathrm{~h}$ an Oil Red O staining was performed to evaluate the amount of lipid droplets. Figure 1 shows the FFA treatment was able to increase the triglycerides storage in HepG2 cells compared to the control untreated group. The group pre-treated with SnMP showed a significative increase of the lipid droplets amount compared to the CTRL and FFA groups, while in the group pre-treated with the combination of SnMP and CoPP this effect was partially reversed, indicating the involvement of the $\mathrm{HO}$ system in the lipid metabolism regulation. 
CTRL

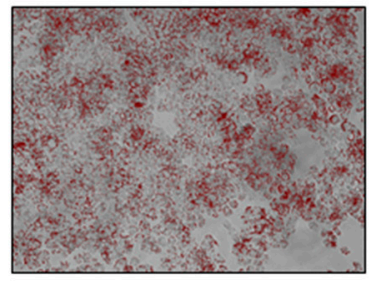

FFA $2 \mathrm{mM}$

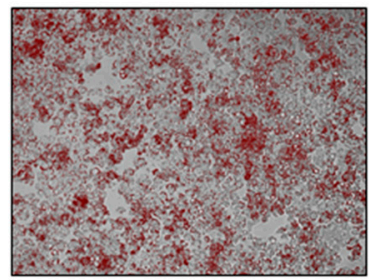

FFA+SnMP $5 \mu M$

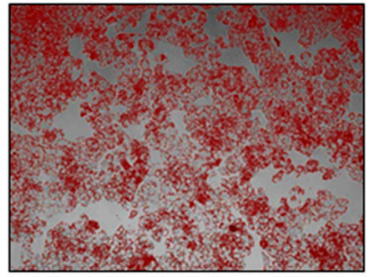

FFA+SnMP+COPP $5 \mu \mathrm{M}$

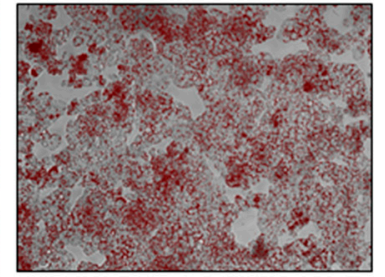

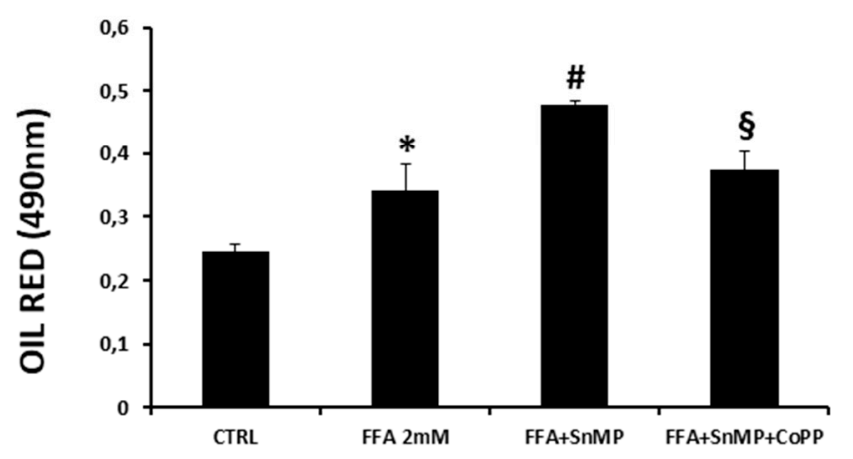

Figure 1. Effect of $\mathrm{HO}$ inhibition on oil droplets formation in hepatocytes. We measured the effect of SnMP $5 \mu \mathrm{M}$ treatment on lipogenesis in the presence of FFA. ${ }^{*} p<0.05$ vs. CTRL, \# $p<0.05$ vs. FFA $2 \mathrm{mM}, \S p<0.05$ vs. FFA+SnMP.

\subsection{Effect of HO Regulation on Lipid Metabolism Pathway}

To support the Oil Red data, we analyzed the mRNA levels of lipid metabolism pathway genes. Figure 2A-C showed an increase of Diglyceride acyltransferase 1 (DGAT-1), Sterol regulatory element-binding transcription factor 1 (SREBP-1) and Fatty acid synthetase (FAS) gene expression in the group with SnMP treatment compared to the control group, suggesting an increased synthesis of cholesterol, fatty acids and triglycerides. The co-treatment with CoPP, a strong inducer of HO-1 expression, reversed the SnMP effect on DGAT-1 and SREBP-1 genes, but did not affect FAS expression. We also analyzed the HO-1 levels (Figure 2D), that were increased in the FFA group when compared with the control group, probably because the FFA treatment causes a moderate oxidative stress. As expected, in the SnMP group, HO-1 was markedly increased compared to the FFA group because, as previous studies demonstrated, SnMP decreased the HO activity, but increased its protein expression $[55,56]$. The group with both compound SnMP and CoPP showed a synergic effect with a strong increase of HO-1 expression compared with all other groups. Sirtuin 1 expression (SIRT1) did not show any difference in mRNA expression, in both groups FFA and FFA-SnMP when compared with the control, but the co-administration of CoPP showed a significant increase compared with other groups (Figure 2E). That result is in accordance with several published studies that demonstrated the positive relation between the $\mathrm{HO}$ and SIRT1 genes expression [57]. 

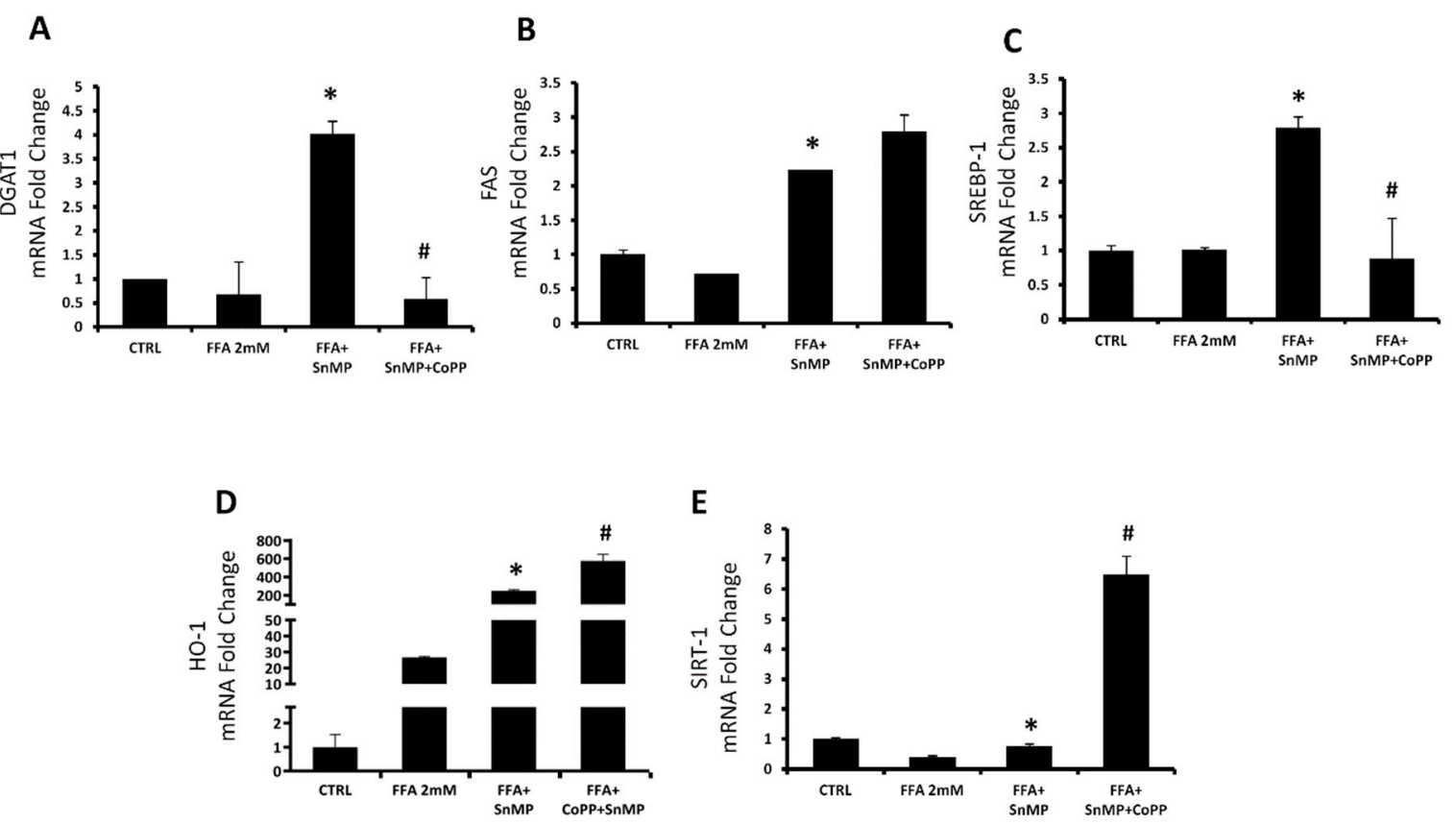

Figure 2. mRNA expression of DGAT1 (A) FAS, (B) SREBP-1, (C) HO-1, and (D) SIRT1, (E) of HepG2 control cells, cells treated with FFA $2 \mathrm{mM}$ and cells treated with SnMP $5 \mathrm{uM}$ alone or in combination with CoPP $5 \mathrm{uM}$. Results are mean $\pm \mathrm{SD},{ }^{*} p<0.05$ vs. FFA $2 \mathrm{mM},{ }^{*} p<0.05$ vs. FFA+SnMP.

\subsection{Hepatic Fibrosis In Vitro Model}

We investigated another main process that characterized the NAFLD physiopathology creating an in vitro model of hepatic fibrosis, administrating to LX2 cells the TGF- $\beta$ protein, that is known to activate fibroblasts resulting in collagen release [58]. We treated LX2 cells with $5 \mathrm{ng} / \mathrm{mL}$ of TGF- $\beta$ and we measured the reactive oxygen species (ROS) generation and the soluble collagen release. ROS production was increased by $72 \%$ after $1 \mathrm{~h}$ in the group with TGF- $\beta 5 \mathrm{ng}$ compared to the control group (Figure 3A). We measured the soluble collagen using a colorimetric kit (Sircol) and we showed a significant increase of collagen release in the group treated with TGF- $\beta 5 \mathrm{ng}$ compared to the control group. Furthermore, we analyzed the mRNA expression of the main genes involved in the collagen production as collagen type 1 alpha 1 (COL1A1), alpha smooth muscle actin ( $\alpha$-SMA), SMAD3, SMAD4, SMAD7 and TIMP-1. As shown in Figure 4, in all the genes the expression was markedly increased by TGF- $\beta$ 5ng treatment compared to the control group. 

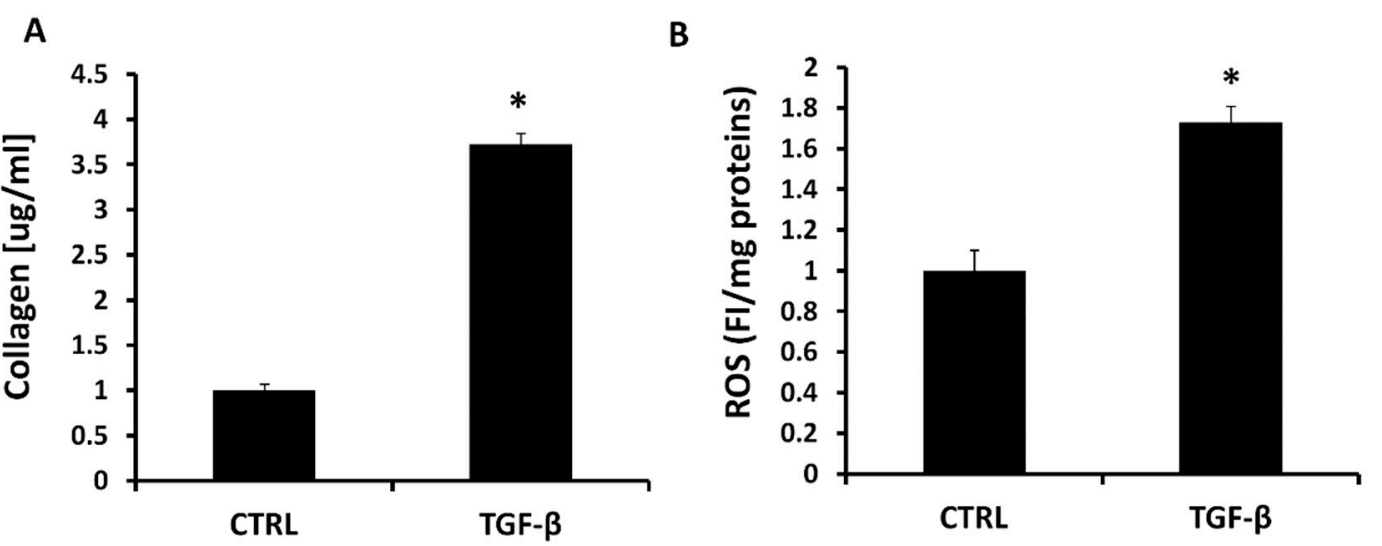

Figure 3. (A) Soluble collagen in LX2 cells activated with TGF- $\beta 5 \mathrm{ng}$ for $24 \mathrm{~h}$. Soluble collagen measurement are expressed as $\mu \mathrm{g} / \mathrm{mL}$. Values represent the means $\pm \mathrm{SD}$ of three experiments performed in triplicate. ${ }^{*} p<0.05$, significant result vs. untreated LX2 cells. (B) Intracellular oxidants in LX2 cells activated with TGF- $\beta$ ng for $1 \mathrm{~h}$. Results are mean \pm SD, $* p<0.05$ vs. CTRL.
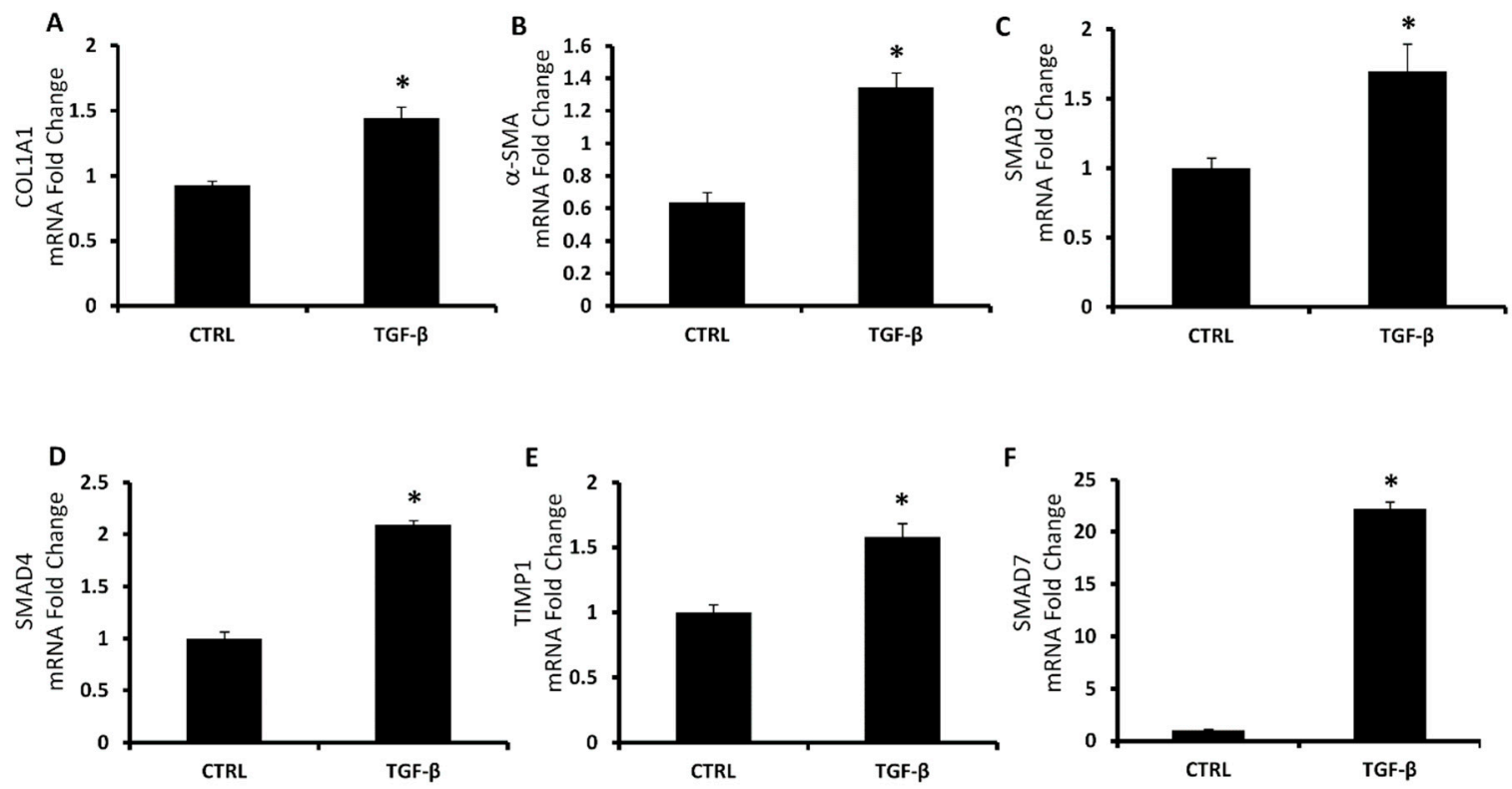

Figure 4. mRNA expression of fibrosis pathway. COL1A1 (A), $\alpha$-SMA (B), SMAD3 (C), SMAD4 (D), TIMP1 (E) and SMAD7 (F) of LX2 control cells and cells treated with TGF- $\beta 5$ ng. Results are mean \pm $\mathrm{SD},{ }^{*} p<0.05$ vs. CTRL.

\subsection{Effect of HO Inhibition on ROS Generation and Soluble Collagen Release}

We investigated the role of HO in this model of fibrosis using SnMP and CoPP, both at the concentration of $5 \mu \mathrm{m}$. In order to confirm the role of ROS in liver fibrosis and if ROS production is regulated by treatment of SnMP with or without CoPP, we evaluated ROS production in LX2 cells by flow-cytometer (Figure 5A). The obtained results showed that SnMP treatment significantly increased ROS generation but co-treatment with CoPP reversed the effect mediated by SnMP (Figure 5B). To investigate the correlation between ROS and fibrosis, we treated LX2 cells with SnMP and CoPP for $2 \mathrm{~h}$ before the administration of TGF- $\beta 5 \mathrm{ng} / \mathrm{ml}$ and we obtained a significant increase in collagen release levels after $3 \mathrm{~h}$ in the group with SnMP compared to the TGF- $\beta$ group (Figure 5C). The effect was reversed by the HO-1 inducer CoPP. 
A

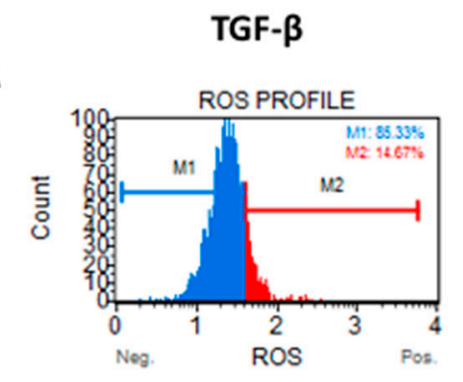

TGF- $\beta+$ SnMP

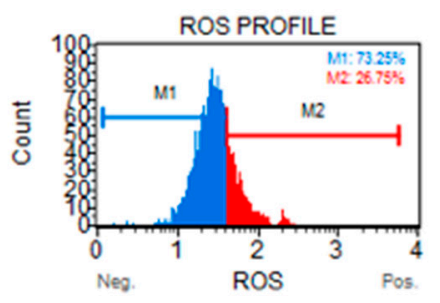

TGF- $\beta+$ SnMP+CoPP

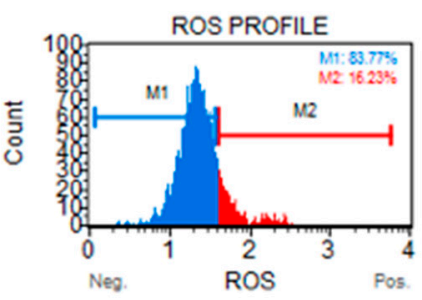

B

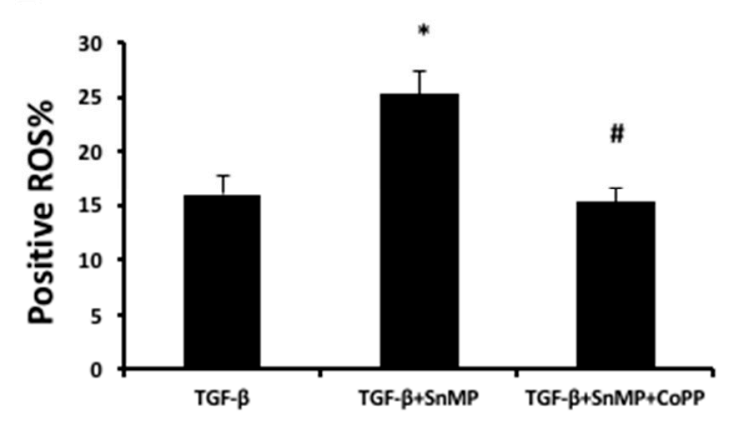

C

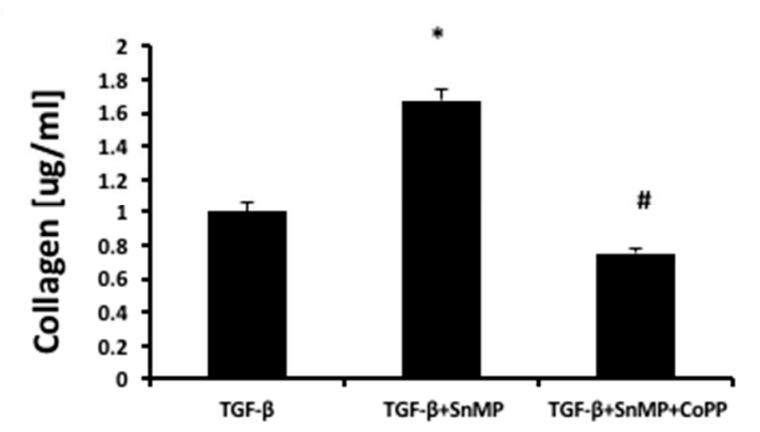

Figure 5. (A) The quantitative measurement of cells undergoing oxidative stress was evaluated by cytometry, using the Muse Oxidative Stress Kit. Cells were pre-treated with SnMP $(5 \mu \mathrm{M})$ and CoPP $(5 \mu \mathrm{M})$ for $24 \mathrm{~h}$ and then incubated for $1 \mathrm{~h}$ with TGF- $\beta 5 \mathrm{ng} / \mathrm{mL}$. (B) The graph showed the positive ROS percentage in the different groups. ${ }^{*} p<0.05$ vs. TGF- $\beta,{ }^{\#} p<0.05$ vs. TGF- $\beta+$ SnMP. (C) Soluble collagen in LX2 cells treated with TGF- $\beta 5 \mathrm{ng} / \mathrm{mL}$ for $24 \mathrm{~h}$ in the presence or absence of SnMP $5 \mu \mathrm{M}$ alone or in combination with CoPP $5 \mu \mathrm{M}$. Soluble collagen measurement is expressed as $\mu \mathrm{g} / \mathrm{mL}$. Values represent the means \pm SD of three experiments performed in triplicate. ${ }^{*} p<0.05$ vs. TGF- $\beta$; $\#<0.05$ vs. TGF- $\beta+$ SnMP.

\section{Discussion}

Considering the complexity of NAFLD and its rising prevalence globally, it is of primary importance to find new protein targets for the regulation of the pathways involved in this pathology. In NAFLD, an increase in hepatic FFAs uptake, lipid synthesis, impaired $\beta$-oxidation, and a decrease in lipid export facilitates accumulation of fat in the liver $[59,60]$. In order to study the role of the HO system in the main NASH pathological aspects, we propose two different in vitro models for steatosis and fibrosis. Primary hepatocytes, derived from human liver samples, are an ideal in vitro model for studying hepatosteatosis, but the difficulty to obtain normal clinical liver samples lead us to use HepG2 cells as an alternative cellular model [52]. Whereas oleic and palmitic acid represent the main fatty acids in the triglycerides (TG) content of steatotic patients, we treated HepG2 cells with a combination of these fatty acids to simulate NAFLD [61]. To assess how $\mathrm{HO}$ affects the hepatocytes lipid metabolism, we cultured the HepG2 cells with a well-known HO activity inhibitor named SnMP, alone or in combination with the strong HO inducer CoPP. Figure 1 shows that FFA was able to increase the intracellular lipid droplets content compared to untreated cells, in particular in the cells that received the pre-treatment with SnMP, suggesting that HO inhibition impairs the lipid metabolism in hepatocytes. SREBP, characterized by the three isoforms SREBP-1a, SREBP-1c and SREBP-2, plays a key role on the regulation of various genes expression involved in cholesterol and lipid metabolism. SREBP-1c represents the major isoform that controls FA synthesis in the liver and is regulated by a series of nutritional and hormonal stimulus through transcriptional and post-transcriptional mechanisms. Yahagi et al. showed that knockout SREBP-1c ob/ob mice presented a significant reduction in the hepatic expression of lipogenic genes preventing liver steatosis [62]. Conversely, overexpression of 
SREBP-1c results in raised levels of FAS, acetyl CoA carboxylase (ACC) and stearoyl-CoA desaturase (SCD) causing an increase in lipogenesis [63] that, in concert with an augmented hepatic FFAs uptake, is known to contribute TG accumulation in the hepatocytes [64]. In HepG2 cells treated with FFA, we observed a significant increase of SREBP-1c, DGAT-1 and FAS levels after SnMP treatment which is associated with an increase of fatty acid storage. Conversely, co-administration of CoPP and SnMP reversed DGAT and SREBP-1c mRNA levels, confirming that HO can affect TG formation and storage in hepatocyte's cytoplasm. As the most extensively studied sirtuin, Sirt1 has a prominent role in metabolic tissues, such as the liver, skeletal muscle and adipose tissues. Sirt1 overexpression in the liver can deacetylate a range of substrates, including SREBP-1c, PGC-1 $\alpha$ and FoxO1 proteins, and can result in a pronounced effect on glucose and lipid metabolism $[65,66]$. Previous studies indicated that the overexpression of Sirt1 protects against HFD-induced hepatic inflammation by decreasing the NFKB-mediated induction of inflammatory cytokines [67]. Consistent with previous published results, our data showed a positive regulation of Sirt1 by HO-1 induction [68]. Despite SnMP not affecting Sirt1 gene levels, induction of HO-1 by CoPP treatment significantly increased Sirt1 mRNA. The crosstalk between HO-1 and Sirt1 may be considered as a pivotal axis against oxidative stress caused by hyperglycemia and hyperlipidemia, and it is essential to protect the liver from steatosis. The results reported here extend our previous findings that upregulation of $\mathrm{HO}-1$ in hepatocytes results in the negative regulation of lipogenesis [68-71]. In order to evaluate the detrimental role of HO-1 inhibition on liver fibrosis, we first established an in vitro model of liver fibrosis using TGF- $\beta$ as a fibrotic agent in human stellate hepatic cells. In chronic liver diseases, hepatic stellate cells have been considered as a primary target for active TGF- $\beta$, thereby cell treatment with TGF- $\beta$ contributes to their activation and subsequent fibrogenesis. The increase of ROS levels mediated by TGF- $\beta$ treatment (Figure 3 ) and lipid peroxidation products contribute to collagen release causing the onset and progression of fibrosis [72]. Blockage of ROS generation by HSC in response to TGF- $\beta$ and alleviation of the downstream proteins is a strategy to inhibit liver fibrosis [73].

As shown in Figure 4, the induction of $\alpha$-SMA, COL1A1 and SMADs represents reliable markers of HSCs activation to myofibroblast-like cells with direct contribution to hepatic fibrogenesis. Heme oxygenase, known to be a powerful antioxidant enzymatic system, plays a key role in redox balance by counteracting ROS production [74]. Liu et al. showed that CoPP upregulates HO-1 and other oxidative stress-responsive genes expression and decreases mitochondria-derived ROS production [75]. Contrarily, SnMP increases ROS and oxidative stress [76]. Consistent with these findings, in the present article, we showed that $\mathrm{HO}$ activity inhibition further increased ROS and collagen release (Figure 5) from activated LX2 compared to cells treated exclusively with TGF- $\beta$. Furthermore, we found that increased HO-1 levels by CoPP reversed the effect mediated by SnMP and reduced the levels of ROS and soluble collagen released from activated LX2. These novel findings underscore the importance of targeting HO-1 and provide additional evidences for a link between liver disorders and the HO system. A limitation of the in vitro study, but in agreement with the report by Schulz et al. [76], although SnMP treatment decreased cellular HO activity, the combination of SnMP+CoPP did not increase the enzymatic activity compared to the SnMP group (data not shown). However, it must be taken into consideration that induction of $\mathrm{HO}-1$ expression presents several non-canonical functions not associated to the enzymatic activity [77]. Consequently, the increase of HO-1 levels may provide a therapeutic approach to address the metabolic alterations associated with NAFLD and its progression to NASH.

Author Contributions: M.R., G.C., L.V., I.B. and G.S. conceptualization, writing original draft preparation; M.R., G.C. and M.L. investigation and formal analysis; L.V. funding acquisition; I.B. and V.S. Resources and writing-review and editing; L.V. and S.S.S. Supervision and Project administration.

Funding: This research was funded by FFABR2017.

Conflicts of Interest: The authors declare no conflict of interest. 


\section{References}

1. Clark, J.M.; Brancati, F.L.; Diehl, A.M. Nonalcoholic fatty liver disease. Gastroenterology 2002, 122, $1649-1657$. [CrossRef] [PubMed]

2. Angulo, P. Nonalcoholic fatty liver disease. N. Engl. J. Med. 2002, 346, 1221-1231. [CrossRef] [PubMed]

3. Hernandez, I.; Dominguez-Perez, M.; Bucio, L.; Souza, V.; Miranda, R.U.; Clemens, D.L.; Gomez-Quiroz, L.E.; Gutierrez-Ruiz, M.C. Free fatty acids enhance the oxidative damage induced by ethanol metabolism in an in vitro model. Food Chem. 2015, 76, 109-115. [CrossRef] [PubMed]

4. Carulli, L.; Zanca, G.; Schepis, F.; Villa, E. The OMICs Window into Nonalcoholic Fatty Liver Disease (NAFLD). Metabolites 2019, 9, 25. [CrossRef] [PubMed]

5. Gorden, D.L.; Myers, D.S.; Ivanova, P.T.; Fahy, E.; Maurya, M.R.; Gupta, S.; Min, J.; Spann, N.J.; McDonald, J.G.; Kelly, S.L.; et al. Biomarkers of NAFLD progression: A lipidomics approach to an epidemic. J. Lipid Res. 2015, 56, 722-736. [CrossRef] [PubMed]

6. Knudsen, C.; Neyrinck, A.M.; Lanthier, N.; Delzenne, N.M. Microbiota and nonalcoholic fatty liver disease: Promising prospects for clinical interventions? Curr. Opin. Clin. Nutr. Metab. Care 2019, 22, 393-400. [CrossRef] [PubMed]

7. Licari, M.; Raffaele, M.; Rosman, Z.F.; Schragenheim, J.; Bellner, L.; Vanella, L.; Rezzani, R.; Rodella, L.; Bonomini, F.; Hochhauser, E.; et al. Beneficial Effects of Thymoquinone on Metabolic Function and Fatty Liver in a Murine Model of Obesity. J. Nutr. Food Sci. 2019, 9. [CrossRef]

8. Fabbrini, E.; Sullivan, S.; Klein, S. Obesity and nonalcoholic fatty liver disease: Biochemical, metabolic, and clinical implications. Hepatology 2010, 51, 679-689. [CrossRef]

9. Adams, L.A.; Lymp, J.F.; St Sauver, J.; Sanderson, S.O.; Lindor, K.D.; Feldstein, A.; Angulo, P. The natural history of nonalcoholic fatty liver disease: A population-based cohort study. Gastroenterology 2005, 129, 113-121. [CrossRef] [PubMed]

10. Lin, B.; Ma, Y.; Wu, S.; Liu, Y.; Liu, L.; Wu, L. Novel Serum Biomarkers for Noninvasive Diagnosis and Screening of Nonalcoholic Fatty Liver Disease-Related Hepatic Fibrosis. OMICS J. Integr. Biol. 2019, 23, 181-189. [CrossRef]

11. Mardinoglu, A.; Uhlen, M.; Boren, J. Broad Views of Non-alcoholic Fatty Liver Disease. Cell Syst. 2018, 6, 7-9. [CrossRef] [PubMed]

12. Wruck, W.; Kashofer, K.; Rehman, S.; Daskalaki, A.; Berg, D.; Gralka, E.; Jozefczuk, J.; Drews, K.; Pandey, V.; Regenbrecht, C.; et al. Multi-omic profiles of human non-alcoholic fatty liver disease tissue highlight heterogenic phenotypes. Sci. Data 2015, 2, 150068. [CrossRef]

13. Kotronen, A.; Yki-Jarvinen, H. Fatty liver: A novel component of the metabolic syndrome. Arterioscler. Thromb. Vasc. Biol. 2008, 28, 27-38. [CrossRef] [PubMed]

14. Patil, R.; Sood, G.K. Non-alcoholic fatty liver disease and cardiovascular risk. World J. Gastrointest. Pathophysiol. 2017, 8, 51-58. [CrossRef] [PubMed]

15. Byrne, C.D.; Targher, G. NAFLD: A multisystem disease. J. Hepatol. 2015, 62, S47-S64. [CrossRef]

16. Idilman, I.S.; Ozdeniz, I.; Karcaaltincaba, M. Hepatic Steatosis: Etiology, Patterns, and Quantification. Semin. Ultrasound CT MR 2016, 37, 501-510. [CrossRef]

17. Lee, P.C.; Yang, L.Y.; Wang, Y.W.; Huang, S.F.; Lee, K.C.; Hsieh, Y.C.; Yang, Y.Y.; Hsieh, S.L.; Hou, M.C.; Lin, H.C.; et al. Mechanisms of the prevention and inhibition of the progression and development of non-alcoholic steatohepatitis by genetic and pharmacological decoy receptor 3 supplementation. Hepatol. Res. 2017, 47, 1260-1271. [CrossRef]

18. Hernandez-Gea, V.; Friedman, S.L. Pathogenesis of liver fibrosis. Annu. Rev. Pathol. 2011, 6, 425-456. [CrossRef]

19. Wallace, K.; Burt, A.D.; Wright, M.C. Liver fibrosis. Biochem. J. 2008, 411, 1-18. [CrossRef]

20. Zhang, H.; Sun, D.; Wang, G.; Cui, S.; Field, R.A.; Li, J.; Zang, Y. Alogliptin alleviates liver fibrosis via suppression of activated hepatic stellate cell. Biochem. Biophys. Res. Commun. 2019, 511, 387-393. [CrossRef]

21. Yin, C.; Evason, K.J.; Asahina, K.; Stainier, D.Y. Hepatic stellate cells in liver development, regeneration, and cancer. J. Clin. Investig. 2013, 123, 1902-1910. [CrossRef]

22. Cordero-Espinoza, L.; Huch, M. The balancing act of the liver: Tissue regeneration versus fibrosis. J. Clin. Investig. 2018, 128, 85-96. [CrossRef] 
23. Fujita, T.; Narumiya, S. Roles of hepatic stellate cells in liver inflammation: A new perspective. Inflamm. Regen. 2016, 36, 1. [CrossRef]

24. Bauge, C.; Cauvard, O.; Leclercq, S.; Galera, P.; Boumediene, K. Modulation of transforming growth factor beta signalling pathway genes by transforming growth factor beta in human osteoarthritic chondrocytes: Involvement of Sp1 in both early and late response cells to transforming growth factor beta. Arthritis Res. Ther. 2011, 13, R23. [CrossRef]

25. Qiang, H.; Lin, Y.; Zhang, X.; Zeng, X.; Shi, J.; Chen, Y.X.; Yang, M.F.; Han, Z.G.; Xie, W.F. Differential expression genes analyzed by cDNA array in the regulation of rat hepatic fibrogenesis. Liver Int. 2006, 26, 1126-1137. [CrossRef]

26. Bi, W.R.; Yang, C.Q.; Shi, Q. Transforming growth factor-beta1 induced epithelial-mesenchymal transition in hepatic fibrosis. Hepatogastroenterology 2012, 59, 1960-1963. [CrossRef]

27. Wrana, J.L.; Attisano, L.; Carcamo, J.; Zentella, A.; Doody, J.; Laiho, M.; Wang, X.F.; Massague, J. TGF beta signals through a heteromeric protein kinase receptor complex. Cell 1992, 71, 1003-1014. [CrossRef]

28. Lan, H.Y.; Chung, A.C. Transforming growth factor-beta and Smads. Contrib. Nephrol. 2011, 170, 75-82. [CrossRef]

29. Xu, F.; Liu, C.; Zhou, D.; Zhang, L. TGF-beta/SMAD Pathway and Its Regulation in Hepatic Fibrosis. J. Histochem. Cytochem. 2016, 64, 157-167. [CrossRef]

30. Navarro-Corcuera, A.; Lopez-Zabalza, M.J.; Martinez-Irujo, J.J.; Alvarez-Sola, G.; Avila, M.A.; Iraburu, M.J.; Ansorena, E.; Montiel-Duarte, C. Role of AGAP2 in the profibrogenic effects induced by TGFbeta in LX-2 hepatic stellate cells. Biochim. Biophys. Acta Mol. Cell Res. 2019, 1866, 673-685. [CrossRef]

31. Rector, R.S.; Thyfault, J.P.; Uptergrove, G.M.; Morris, E.M.; Naples, S.P.; Borengasser, S.J.; Mikus, C.R.; Laye, M.J.; Laughlin, M.H.; Booth, F.W.; et al. Mitochondrial dysfunction precedes insulin resistance and hepatic steatosis and contributes to the natural history of non-alcoholic fatty liver disease in an obese rodent model. J. Hepatol. 2010, 52, 727-736. [CrossRef]

32. Choudhury, M.; Jonscher, K.R.; Friedman, J.E. Reduced mitochondrial function in obesity-associated fatty liver: SIRT3 takes on the fat. Aging 2011,3, 175-178. [CrossRef]

33. Okura, Y.; Namisaki, T.; Moriya, K.; Kitade, M.; Takeda, K.; Kaji, K.; Noguchi, R.; Nishimura, N.; Seki, K.; Kawaratani, H.; et al. Combined treatment with dipeptidyl peptidase-4 inhibitor (sitagliptin) and angiotensin-II type 1 receptor blocker (losartan) suppresses progression in a non-diabetic rat model of steatohepatitis. Hepatol. Res. 2017, 47, 1317-1328. [CrossRef]

34. Gozzelino, R.; Jeney, V.; Soares, M.P. Mechanisms of cell protection by heme oxygenase-1. Annu. Rev. Pharmacol. Toxicol. 2010, 50, 323-354. [CrossRef]

35. Maines, M.D. The heme oxygenase system: Past, present, and future. Antioxid. Redox Signal. 2004, 6, 797-801. [CrossRef]

36. Signorelli, S.S.; Li Volsi, G.; Fiore, V.; Mangiafico, M.; Barbagallo, I.; Parenti, R.; Rizzo, M.; Li Volti, G. Plasma heme oxygenase- 1 is decreased in peripheral artery disease patients. Mol. Med. Rep. 2016, 14, 3459-3463. [CrossRef]

37. Otterbein, L.E.; Choi, A.M. Heme oxygenase: Colors of defense against cellular stress. Am. J. Physiol. Lung Cell. Mol. Physiol. 2000, 279, L1029-L1037. [CrossRef]

38. Zingales, V.; Distefano, A.; Raffaele, M.; Zanghi, A.; Barbagallo, I.; Vanella, L. Metformin: A Bridge between Diabetes and Prostate Cancer. Front. Oncol. 2017, 7, 243. [CrossRef]

39. Barbagallo, I.; Giallongo, C.; Volti, G.L.; Distefano, A.; Camiolo, G.; Raffaele, M.; Salerno, L.; Pittala, V.; Sorrenti, V.; Avola, R.; et al. Heme Oxygenase Inhibition Sensitizes Neuroblastoma Cells to Carfilzomib. Mol. Neurobiol. 2019, 56, 1451-1460. [CrossRef]

40. Raffaele, M.; Pittala, V.; Zingales, V.; Barbagallo, I.; Salerno, L.; Li Volti, G.; Romeo, G.; Carota, G.; Sorrenti, V.; Vanella, L. Heme Oxygenase-1 Inhibition Sensitizes Human Prostate Cancer Cells towards Glucose Deprivation and Metformin-Mediated Cell Death. Int. J. Mol. Sci. 2019, 20, 2593. [CrossRef]

41. Vanella, L.; Di Giacomo, C.; Acquaviva, R.; Barbagallo, I.; Li Volti, G.; Cardile, V.; Abraham, N.G.; Sorrenti, V. Effects of ellagic Acid on angiogenic factors in prostate cancer cells. Cancers 2013, 5, 726-738. [CrossRef]

42. Carota, G.; Sferrazzo, G.; Spampinato, M.; Sorrenti, V.; Vanella, L. Antiproliferative Effects of Ellagic Acid on DU145 Cells. Open Biochem. J. 2019, 13, 23-31. [CrossRef]

43. Wilks, A. Heme oxygenase: Evolution, structure, and mechanism. Antioxid. Redox Signal. 2002, 4, 603-614. [CrossRef] 
44. Goda, N.; Suzuki, K.; Naito, M.; Takeoka, S.; Tsuchida, E.; Ishimura, Y.; Tamatani, T.; Suematsu, M. Distribution of heme oxygenase isoforms in rat liver. Topographic basis for carbon monoxide-mediated microvascular relaxation. J. Clin. Investig. 1998, 101, 604-612. [CrossRef]

45. Abraham, N.G.; Junge, J.M.; Drummond, G.S. Translational Significance of Heme Oxygenase in Obesity and Metabolic Syndrome. Trends Pharmacol. Sci. 2016, 37, 17-36. [CrossRef]

46. Raffaele, M.; Li Volti, G.; Barbagallo, I.A.; Vanella, L. Therapeutic Efficacy of Stem Cells Transplantation in Diabetes: Role of Heme Oxygenase. Front. Cell Dev. Biol. 2016, 4, 80. [CrossRef]

47. Liu, L.; Puri, N.; Raffaele, M.; Schragenheim, J.; Singh, S.P.; Bradbury, J.A.; Bellner, L.; Vanella, L.; Zeldin, D.C.; Cao, J.; et al. Ablation of soluble epoxide hydrolase reprogram white fat to beige-like fat through an increase in mitochondrial integrity, HO-1-adiponectin in vitro and in vivo. Prostaglandins Other Lipid Mediat. 2018, 138, 1-8. [CrossRef]

48. Malaguarnera, L.; Madeddu, R.; Palio, E.; Arena, N.; Malaguarnera, M. Heme oxygenase-1 levels and oxidative stress-related parameters in non-alcoholic fatty liver disease patients. J. Hepatol. 2005, 42, 585-591. [CrossRef]

49. Sass, G.; Seyfried, S.; Parreira Soares, M.; Yamashita, K.; Kaczmarek, E.; Neuhuber, W.L.; Tiegs, G. Cooperative effect of biliverdin and carbon monoxide on survival of mice in immune-mediated liver injury. Hepatology 2004, 40, 1128-1135. [CrossRef]

50. Yachie, A.; Niida, Y.; Wada, T.; Igarashi, N.; Kaneda, H.; Toma, T.; Ohta, K.; Kasahara, Y.; Koizumi, S. Oxidative stress causes enhanced endothelial cell injury in human heme oxygenase-1 deficiency. J. Clin. Investig. 1999, 103, 129-135. [CrossRef]

51. Barbagallo, I.; Volti, G.L.; Raffaele, M.; Distefano, A.; Palmeri, R.; Parafati, L.; Licari, M.; Zingales, V.; Avola, R.; Vanella, L. The effects of olive leaf extract from a Sicilian cultivar in an experimental model of hepatic steatosis. Rend Lincei 2017, 28, 643-650. [CrossRef]

52. Feldstein, A.E.; Canbay, A.; Guicciardi, M.E.; Higuchi, H.; Bronk, S.F.; Gores, G.J. Diet associated hepatic steatosis sensitizes to Fas mediated liver injury in mice. J. Hepatol. 2003, 39, 978-983. [CrossRef]

53. Park, M.; Yoo, J.H.; Lee, Y.S.; Lee, H.J. Lonicera caerulea Extract Attenuates Non-Alcoholic Fatty Liver Disease in Free Fatty Acid-Induced HepG2 Hepatocytes and in High Fat Diet-Fed Mice. Nutrients 2019, 11, 494. [CrossRef]

54. Hempel, S.L.; Buettner, G.R.; O’Malley, Y.Q.; Wessels, D.A.; Flaherty, D.M. Dihydrofluorescein diacetate is superior for detecting intracellular oxidants: Comparison with $2^{\prime}, 7^{\prime}$-dichlorodihydrofluorescein diacetate, 5(and 6)-carboxy-2', 7'-dichlorodihydrofluorescein diacetate, and dihydrorhodamine 123. Free Radic. Biol. Med. 1999, 27, 146-159. [CrossRef]

55. Abate, A.; Zhao, H.; Wong, R.J.; Stevenson, D.K. The role of Bach1 in the induction of heme oxygenase by tin mesoporphyrin. Biochem. Biophys. Res. Commun. 2007, 354, 757-763. [CrossRef]

56. Sardana, M.K.; Kappas, A. Dual control mechanism for heme oxygenase: Tin(IV)-protoporphyrin potently inhibits enzyme activity while markedly increasing content of enzyme protein in liver. Proc. Natl. Acad. Sci. USA 1987, 84, 2464-2468. [CrossRef]

57. Liu, X.; Gao, Y.; Li, M.; Geng, C.; Xu, H.; Yang, Y.; Guo, Y.; Jiao, T.; Fang, F.; Chang, Y. Sirt1 mediates the effect of the heme oxygenase inducer, cobalt protoporphyrin, on ameliorating liver metabolic damage caused by a high-fat diet. J. Hepatol. 2015, 63, 713-721. [CrossRef]

58. Presser, L.D.; McRae, S.; Waris, G. Activation of TGF-beta1 promoter by hepatitis C virus-induced AP-1 and Sp1: Role of TGF-beta1 in hepatic stellate cell activation and invasion. PLoS ONE 2013, 8, e56367. [CrossRef]

59. Koutsari, C.; Mundi, M.S.; Ali, A.H.; Patterson, B.W.; Jensen, M.D. Systemic free fatty acid disposal into very low-density lipoprotein triglycerides. Diabetes 2013, 62, 2386-2395. [CrossRef]

60. Dhami-Shah, H.; Vaidya, R.; Udipi, S.; Raghavan, S.; Abhijit, S.; Mohan, V.; Balasubramanyam, M.; Vaidya, A. Picroside II attenuates fatty acid accumulation in HepG2 cells via modulation of fatty acid uptake and synthesis. Clin. Mol. Hepatol. 2018, 24, 77-87. [CrossRef]

61. Gomez-Lechon, M.J.; Donato, M.T.; Martinez-Romero, A.; Jimenez, N.; Castell, J.V.; O'Connor, J.E. A human hepatocellular in vitro model to investigate steatosis. Chem. Biol. Interact. 2007, 165, 106-116. [CrossRef]

62. Yahagi, N.; Shimano, H.; Hasty, A.H.; Matsuzaka, T.; Ide, T.; Yoshikawa, T.; Amemiya-Kudo, M.; Tomita, S.; Okazaki, H.; Tamura, Y.; et al. Absence of sterol regulatory element-binding protein-1 (SREBP-1) ameliorates fatty livers but not obesity or insulin resistance in Lep(ob)/Lep(ob) mice. J. Biol. Chem. 2002, 277, 19353-19357. [CrossRef] 
63. Pettinelli, P.; Obregon, A.M.; Videla, L.A. Molecular mechanisms of steatosis in nonalcoholic fatty liver disease. Nutr. Hosp. 2011, 26, 441-450. [CrossRef]

64. Lambert, J.E.; Ramos-Roman, M.A.; Browning, J.D.; Parks, E.J. Increased de novo lipogenesis is a distinct characteristic of individuals with nonalcoholic fatty liver disease. Gastroenterology 2014, 146, 726-735. [CrossRef]

65. Liang, F.; Kume, S.; Koya, D. SIRT1 and insulin resistance. Nat. Rev. Endocrinol. 2009, 5, 367-373. [CrossRef]

66. Ponugoti, B.; Kim, D.H.; Xiao, Z.; Smith, Z.; Miao, J.; Zang, M.; Wu, S.Y.; Chiang, C.M.; Veenstra, T.D.; Kemper, J.K. SIRT1 deacetylates and inhibits SREBP-1C activity in regulation of hepatic lipid metabolism. J. Biol. Chem. 2010, 285, 33959-33970. [CrossRef]

67. Pfluger, P.T.; Herranz, D.; Velasco-Miguel, S.; Serrano, M.; Tschop, M.H. Sirt1 protects against high-fat diet-induced metabolic damage. Proc. Natl. Acad. Sci. USA 2008, 105, 9793-9798. [CrossRef]

68. Sacerdoti, D.; Singh, S.P.; Schragenheim, J.; Bellner, L.; Vanella, L.; Raffaele, M.; Meissner, A.; Grant, I.; Favero, G.; Rezzani, R.; et al. Development of NASH in Obese Mice is Confounded by Adipose Tissue Increase in Inflammatory NOV and Oxidative Stress. Int. J. Hepatol. 2018, 2018, 3484107. [CrossRef]

69. Raffaele, M.; Bellner, L.; Singh, S.P.; Favero, G.; Rezzani, R.; Rodella, L.F.; Falck, J.R.; Abraham, N.G.; Vanella, L. Epoxyeicosatrienoic intervention improves NAFLD in leptin receptor deficient mice by an increase in PGC1alpha-HO-1-PGC1alpha-mitochondrial signaling. Exp. Cell Res. 2019, 380, 180-187. [CrossRef]

70. Sodhi, K.; Puri, N.; Favero, G.; Stevens, S.; Meadows, C.; Abraham, N.G.; Rezzani, R.; Ansinelli, H.; Lebovics, E.; Shapiro, J.I. Fructose Mediated Non-Alcoholic Fatty Liver Is Attenuated by HO-1-SIRT1 Module in Murine Hepatocytes and Mice Fed a High Fructose Diet. PLoS ONE 2015, 10, e0128648. [CrossRef]

71. Hinds, T.D., Jr.; Sodhi, K.; Meadows, C.; Fedorova, L.; Puri, N.; Kim, D.H.; Peterson, S.J.; Shapiro, J.; Abraham, N.G.; Kappas, A. Increased HO-1 levels ameliorate fatty liver development through a reduction of heme and recruitment of FGF21. Obesity 2014, 22, 705-712. [CrossRef]

72. Mostafa, M.E.; Shaaban, A.A.; Salem, H.A. Dimethylfumarate ameliorates hepatic injury and fibrosis induced by carbon tetrachloride. Chem. Biol. Interact. 2019, 302, 53-60. [CrossRef]

73. Yang, K.L.; Chang, W.T.; Hong, M.Y.; Hung, K.C.; Chuang, C.C. Prevention of TGF-beta-induced early liver fibrosis by a maleic acid derivative anti-oxidant through suppression of ROS, inflammation and hepatic stellate cells activation. PLoS ONE 2017, 12, e0174008. [CrossRef]

74. Rochette, L.; Zeller, M.; Cottin, Y.; Vergely, C. Redox Functions of Heme Oxygenase-1 and Biliverdin Reductase in Diabetes. Trends Endocrinol. Metab. TEM 2018, 29, 74-85. [CrossRef]

75. Liu, X.; Cui, Y.; Li, M.; Xu, H.; Zuo, J.; Fang, F.; Chang, Y. Cobalt protoporphyrin induces HO-1 expression mediated partially by FOXO1 and reduces mitochondria-derived reactive oxygen species production. PLoS ONE 2013, 8, e80521. [CrossRef]

76. Waldman, M.; Nudelman, V.; Shainberg, A.; Zemel, R.; Kornwoski, R.; Aravot, D.; Peterson, S.J.; Arad, M.; Hochhauser, E. The Role of Heme Oxygenase 1 in the Protective Effect of Caloric Restriction against Diabetic Cardiomyopathy. Int. J. Mol. Sci. 2019, 20, 2427. [CrossRef]

77. Vanella, L.; Barbagallo, I.; Tibullo, D.; Forte, S.; Zappala, A.; Li Volti, G. The non-canonical functions of the heme oxygenases. Oncotarget 2016, 7, 69075-69086. [CrossRef]

(C) 2019 by the authors. Licensee MDPI, Basel, Switzerland. This article is an open access article distributed under the terms and conditions of the Creative Commons Attribution (CC BY) license (http://creativecommons.org/licenses/by/4.0/). 